\title{
Synthesis and biological evaluation of 3-alkyloxazolidin-2-ones as reversible MAO inhibitors
}

\author{
Claudia Lamanna, ${ }^{a}$ Maria Stefania Sinicropi, ${ }^{\mathrm{b}}$ Paola Pietrangeli,, ${ }^{\mathrm{c}}$ Filomena Corbo,, Carlo \\ Franchini, ${ }^{a}$ Bruno Mondovì, ${ }^{c}$ Maria Grazia Perrone, ${ }^{a}$ and Antonio Scilimati*,a \\ ${ }^{a}$ Dipartimento Farmaco-Chimico, Università degli Studi di Bari, \\ Via E. Orabona n. 4 - 70125 Bari, Italy. \\ ${ }^{b}$ Dipartimento di Scienze Farmaceutiche, Università della Calabria, \\ 87036 Arcavacata di Rende (CS), Italy. \\ ${ }^{c}$ Dipartimento di Scienze Biochimiche "A. Rossi Fanelli” and \\ Istituto di Biologia e Patologia Molecolari del CNR, \\ Università degli Studi di Roma "La Sapienza”, P.le A. Moro n. 5-00185 Roma, Italy \\ E-mail: ascilimati@farmchim.uniba.it
}

In honour of Professor Vincenzo Tortorella in the occasion of his "Fuori Ruolo" status

(received 14 Dec 03; accepted 17 Feb 04; published on the web 21 Feb 04)

\begin{abstract}
The discovery of the two forms of MAO had led to significant advances in the understanding of the physiological and biochemical roles that these enzymes play in normal processes and in disease states. The recent development of a new generation of highly selective reversible MAO inhibitors (MAOIs) have led to a renewed interest in the therapeutic potential of these new compounds with respect to early irreversible MAOIs. In fact, reversible MAOIs offer new hopes for generating superior anti-depressant and anti-parkinsonian agents by virtue of the selective inhibition of MAO-A and MAO-B, respectively. Aryloxazolidinones are one of the relatively new classes of MAOIs. Their "lead compound" is Toloxatone (Humoryl ${ }^{\text {) }}$ ), the first reversible and selective MAO-A inhibitor introduced in clinical practice as an anti-depressant. In order to investigate the importance and hence the biological role played by the anisyl ( $p$-methoxyphenyl) group linked to $\mathrm{N}_{3}$ atom of Toloxatone oxazolidinone ring or more in general of an aromatic group, some new $\mathrm{N}_{3}$-alkyloxazolidinones were synthesized and their ability to inhibit MAO-A and MAO-B enzymes was evaluated by a fluorimetric method that uses the kynuramine as substrate. Also modifications at $\mathrm{C}_{5}$ of the 2-oxazolidinone ring were considered. The set of $\mathrm{N}_{3}$ alkyl substituted and at $\mathrm{C}_{5}$ modified compounds showed ability to inhibit MAO-A and MAO-B but with lower extent than Toloxatone used as reference drug. Such biological results provide insights into structure-activity relationships, confirming that is necessary the presence of $\mathrm{N}_{3}$-aryl moiety to act as a potent reversible MAO inhibitor, not possible in the same extent when the aryl is replaced by an alkyl group $\left(\mathrm{Ki} \approx 10^{-7} \mathrm{M}\right.$ versus $\left.10^{-3}-10^{-4} \mathrm{M}\right)$.
\end{abstract}

Keywords: MAO-A, MAO-B, MAO inhibitors, oxazolidinones 


\section{Introduction}

Similar to other neurotransmitting systems, the catecholamines are massively liberated in the synaptic space after a depolarization of the presynaptic membrane. They, then, act at the receptor level and are subsequently eliminated rapidly by two main mechanisms: catabolism and reuptake.

Inactivation of the effects of catecholamines at the sympathetic neuroeffector junction can take place by one or more mechanisms: a) uptake or reuptake, b) $O$-methylation, c) oxidative deamination.

The two main degradation pathways of these endogen amines are represented both by oxidative deamination, due to the presence of MAO enzymes (monoamino oxidase) and $O$ methylation, catalyzed by COMT enzymes (Catechol-O-methyl transferase). ${ }^{1}$

Neuronal MAO is a flavine containing enzyme and is mainly located on the outer membrane of the mitochondria at the catecholaminergic terminals. ${ }^{2}$

MAO is important in regulating the levels of catecholamines in tissues (particularly intraneuronally), but can also act on the 3-O-methyl metabolites of catecholamines (i.e., COMT then MAO). Thus, the major metabolite of norepinephrine and epinephrine that appears in urine is 3-methoxy-4-hydroxymandelic acid also called vanillylmandelic acid (VMA).

So far, at least two isoforms of neuronal MAO have been recognized: MAO-A and MAO-B, deriving from two different genes that are identified on the basis of their specificity for inhibitor and substrate. MAO-A enzyme preferably metabolizes serotonine and noradrenaline, and is inhibited by clorgyline; MAO-B enzyme preferencially metabolizes dopamine and is inhibited by deprenyl. ${ }^{2}$

In the actual pharmacological therapy, several drugs with anti-MAO properties are commonly used. These compounds, block degradation of the endogen amines, determine an increment of their concentration and are thus useful for those pathologies where the neuronal transmission is faulting. ${ }^{3}$ However, these drugs are almost always not selective. In particular, selective inhibitors of MAO-A seem to be useful in the treatment of the depression, while MAOB inhibitors, by determining an increased synaptic availability for dopamine, are used as agents for the treatment of the Parkinson's disease. ${ }^{4}$

Recent studies showed that derivatives such as 3-aryloxazolidin-2-one (oxazolidinones, Figure 1) are regularly used to treat infections caused by those Gram positive agents, ${ }^{5,6}$ that are resistant to traditional antibiotic agents, here represent a new class of reversible as well irreversible inhibitors for MAO-A and MAO-B enzymes. Hence, these antibacterial agents are able to inhibit protein synthesis ${ }^{7,8}$ and are also used for neurodegenerative type pathologies. The 3-phenyloxazolidin-2-one derivatives substituted in position 5 with alcoholic or ethereal group (Toloxatone, Cimoxatone, Figure 1) are proved to be anti-depressant agents, while the 5-amino3-phenyloxazolidin-2-one derivatives are effective as anti-Parkinson agents (e.g., Almoxatone, MD 780236, Figure 1). ${ }^{8}$

The inhibition produced by these molecules is stereoselective due to the presence of a stereogenic center. The most powerful and selective MAO-A inhibitors have $(R)$-configuration 
(e.g. Cimoxatone, Tolaxotane, etc.). In particular, $(R, S)$-Toloxatone has $\mathrm{Ki}=1.8 \mu \mathrm{M}$ (MAO-A) and $\mathrm{Ki}=44 \mu \mathrm{M}(\mathrm{MAO}-\mathrm{B})$; whereas $(R)$-Toloxatone has $\mathrm{Ki}=0.8 \mu \mathrm{M}(\mathrm{MAO}-\mathrm{A})$ and $\mathrm{Ki}=38.9 \mu \mathrm{M}$ (MAO-B); (S)-Toloxatone has $\mathrm{Ki}=12.5 \mu \mathrm{M}$ (MAO-A) and $\mathrm{Ki}=78.6 \mu \mathrm{M}$ (MAO-B). On the contrary, the most powerful and selective MAO-B inhibitors have $(S)$-configuration [e.g. $(R)$ Almoxatone has $\mathrm{Ki}=1.77 \mu \mathrm{M}(\mathrm{MAO}-\mathrm{A})$ and $\mathrm{Ki}=0.28 \mu \mathrm{M}(\mathrm{MAO}-\mathrm{B}),(S)$-Almoxatone has $\mathrm{Ki}=$ $0.38 \mu \mathrm{M}$ (MAO-A) and $\mathrm{Ki}=0.17 \mu \mathrm{M}(\mathrm{MAO}-\mathrm{B})] .^{9,10}$

Oxazolidinones derivatives are particularly versatile drugs whose study is extremely relevant from a pharmacological point of view. ${ }^{11-15}$ Continuing our studies aimed at developing new potent and more selective $\beta$-adrenoceptor antagonists, ${ }^{16}$ some oxazolidinones were prepared as synthetic suitable precursors of aryloxypropanolamines. In this paper, we report the synthesis of a set of racemic and enantiomerically pure $\mathrm{N}_{3}$-alkyl substituted oxazolidinones as well as their pharmacological evaluation as inhibitors of the two MAO-isomeric forms. This set of compounds is structurally different from the already known reversible MAOIs because an alkyl group is bonded to the $\mathrm{N}_{3}$ atom of the 2-oxazolidinone ring, instead of an aromatic one such as in Toloxatone, Cimoxatone, Almoxatone, etc. (Figure 1). Among these molecules there are also some modification at the methylene- $\mathrm{C}_{5}$ of the oxazolidin-2-one. The results of such an investigation are reported below.

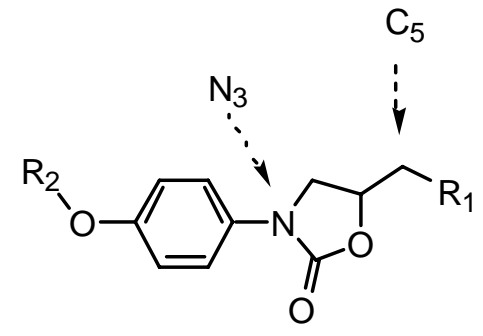

$$
\begin{array}{ll}
\mathrm{R}_{1}=\mathrm{OH} ; \mathrm{R}_{2}=\mathrm{CH}_{3} & \text { TOLOXATONE } \\
\mathrm{R}_{1}=\mathrm{OCH}_{3} ; \mathrm{R}_{2}=(3-\mathrm{CN})-\mathrm{C}_{6} \mathrm{H}_{4} \mathrm{CH}_{2} & \text { CIMOXATONE } \\
\mathrm{R}_{1}=\mathrm{NHCH}_{3} ; \mathrm{R}_{2}=(3-\mathrm{Cl})-\mathrm{C}_{6} \mathrm{H}_{4} \mathrm{CH}_{2} & \text { ALMOXATONE (MD 780236) }
\end{array}
$$

\section{Figure 1}

\section{Chemistry}

$\mathrm{N}_{3}$-sustituted oxazolidin-2-ones synthesis has been accomplished as depicted in Scheme 1 and 2. The first step (Scheme 1, step a) consists of a reaction between racemic and/or optically active $(R)$ - or $(S)$-glycidol and the appropriate amines 2a-e, to give 3a-e in high yields. The second step (Scheme 1, step b) is a cyclization reaction of 3a-e with diethylcarbonate performed in the presence of anhydrous sodium methoxide. 4a-e were obtained in 30-40\% yield. 


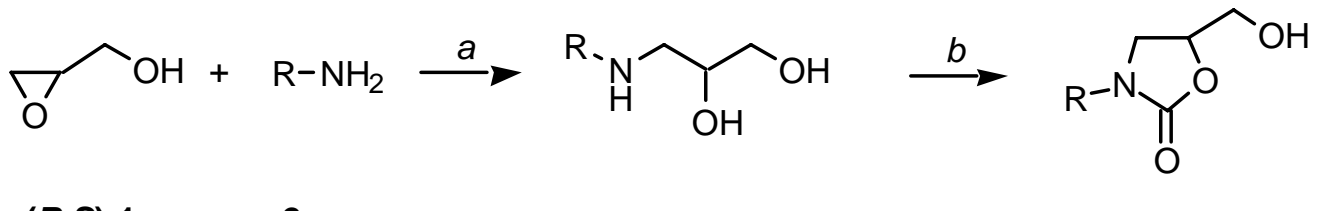
$(R, S)-1$,
$2 a-e$
$3 a-e$
$4 a-e$

$(R)-1$ or $(S)-1$

a: $E t O H, t=25^{\circ} \mathrm{C}, 3 \mathrm{~h}$

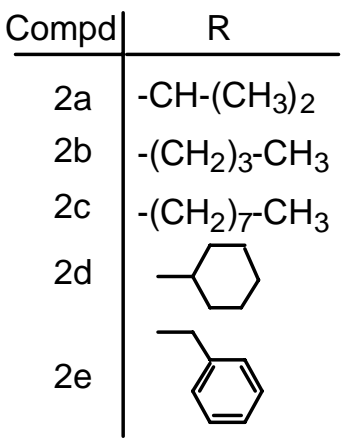

b: $(\mathrm{EtO})_{2} \mathrm{CO} / \mathrm{CH}_{3} \mathrm{ONa}$, reflux, $4 \mathrm{~h}$

\section{Scheme 1}

3-Alkyl-5-(toluenesulfonyloxymethyl)oxazolidin-2-ones [(R,S)-5a, $(R)-5 \mathbf{a},(S)-5 \mathbf{a},(R, S)-5 \mathbf{b}]$ have been prepared in $20 \%$ yield by reacting, respectively, $(R, S)-\mathbf{4 a},(R)-\mathbf{4 a},(S)-\mathbf{4 a}$ and $(R, S)-\mathbf{4 b}$ with $p$-toluenesulfonyl chloride in the presence of pyridine at room temperature (Scheme 2, step a). 3-Isopropyl-5-(benzothiazolylmethyl-2-ylsulfanyl)oxazolidin-2-one $[(R, S)-6 a]$ and its enantiomers have been prepared from (R,S)-5a, $(R)-5 \mathbf{a}$ and $(S)-5 \mathbf{a}$ and the 2mercaptobenzothiazole in $\mathrm{MeOH}$ (Scheme 2, step b).<smiles>[R]N1CC(CO)OC1=O</smiles>

$4 a, 4 b$

a: $p$-toluenesulfonyl chloride pyridine, r.t., $16 \mathrm{~h}$
$5 a, 5 b$

\begin{tabular}{c|c} 
Compd & $\mathrm{R}$ \\
\hline $5 \mathrm{a}$ & $-\mathrm{CH}-\left(\mathrm{CH}_{3}\right)_{2}$ \\
$5 b$ & $-\left(\mathrm{CH}_{2}\right)_{3}-\mathrm{CH}_{3}$
\end{tabular}

b: 2-mercaptobenzothiazole $\mathrm{CH}_{3} \mathrm{OH}$, reflux, $8 \mathrm{~h}$

\section{Scheme 2}




\section{Results and Discussion}

The compounds reported in Table 1 have been synthesized in enantiomerically pure and/or racemic form through the synthetic route depicted in Scheme 1 and 2. This synthetic strategy proved to be particularly advantageous since the use of easy-to-find and low cost starting materials is foreseen and a few reaction steps will easily led to the compounds to be pharmacologically evaluated.

These molecules were biologically tested by bovine brain mitochondria as enzyme source. Activities of MAO-A and MAO-B were determined by a fluorimetric method with the kynuramine as substrate.

The structural modification present in all the compounds, here below described, with respect to well-known MAOIs would provide useful information on the electronic and steric requirements of the active site of the two enzymes. In particular, to the nitrogen atom of the oxazolidinone ring are bonded alkyl groups of different shape and size and on methylene- $\mathrm{C}_{5}$ directly bonded to the ring there is an aromatic moiety such as the p-toluenesulfonyl or benzothiazolyl-2-thiol. On the contrary, in the Toloxatone molecule the nitrogen atom bears an aryl such as the anisyl ( $p$ methoxyphenyl) and to the methylene is bonded only a hydroxy group. Hence, the structural modifications introduced would provide insights on the stereoelectronic demand of the two enzyme catalytic site. Biological data of oxazolidinones bearing on $\mathrm{C}_{5}$ amine, amide and ester functionality other than the hydroxy group and always on $\mathrm{N}_{3}$ an aromatic group have also been reported. Instead, the compounds here described bear on the $\mathrm{N}_{3}$ an alkyl, cycloalkyl and benzyl residue, and on $\mathrm{C}_{5}$-methylene bearing a hydroxy, benzothiazolyl-2-thiol and p-toluenesulfonyl group. The results obtained are summarized in the Table 1.

All the compounds have shown an inhibitory activity ( $\mathrm{Ki}$ around $10^{-3} \mathrm{M}$ ) less than Toloxatone $\left(\mathrm{Ki} \approx 10^{-7} \mathrm{M}\right)$ and than many other reported compounds in which the $\mathrm{C}_{5}$ bonds an aromatic or heteroaromatic group.

In particular, racemic mixture $(R, S)$-4a was only two-fold less potent than the corresponding enantiomers (S)-4a and $(R)-\mathbf{4 a}$ showing a Ki value of $3 \cdot 10^{-3}, 7 \cdot 10^{-3}$ and $8 \cdot 10^{-3} \mathrm{M}$, respectively, that in turn resulted instead equipotent. Similarly, $(R, S)-5 \mathbf{a}\left(\mathrm{Ki}=0.3 \cdot 10^{-3} \mathrm{M}\right)$ was ten-fold more potent than its single enantiomers $(S)-5 \mathbf{a}\left(\mathrm{Ki}=3 \cdot 10^{-3} \mathrm{M}\right)$ and $(R)-5 \mathbf{a}\left(\mathrm{Ki}=2 \cdot 10^{-3} \mathrm{M}\right)$, and also than $(R, S)-\mathbf{4 a}\left(\mathrm{Ki}=3 \cdot 10^{-3} \mathrm{M}\right)$. On the contrary, $(R, S)-6 \mathbf{a}\left(\mathrm{Ki}=0.6 \cdot 10^{-3} \mathrm{M}\right),(S)-6 \mathbf{a}\left(\mathrm{Ki}=0.6 \cdot 10^{-3} \mathrm{M}\right)$ and $(R)-6 \mathbf{a}\left(\mathrm{Ki}=0.5 \cdot 10^{-3} \mathrm{M}\right)$ were equipotent. The structural difference between $(R, S)-\mathbf{4 a}$ with respect to $(R, S)-5 \mathbf{a}$ and $(R, S)-\mathbf{6 a}$ is the presence of an aromatic moiety bonded through the methylene- $\mathrm{C}_{5}$.

$(R, S)-\mathbf{4 d}$ resulted the less potent of the set having a $\mathrm{Ki}=10^{-2} \mathrm{M} .(R, S)-4 \mathrm{c}$ and $(R, S)-4 \mathbf{e}$ are endowed with the same MAOs inhibitory activity having $\mathrm{Ki}=0.4 \cdot 10^{-3} \mathrm{M}$ and $0.5 \cdot 10^{-3} \mathrm{M}$, respectively.

It is noteworth that $(R, S)-\mathbf{4 e}$ is much less active than Toloxatone. This means that the high anti-MAOs activity of Toloxatone compared with $(R, S)-4 \mathbf{e}$ is strictly related to the presence on $\mathrm{N}_{3}$ of the oxazolidinone ring of an aromatic moiety and that the benzyl group does not exert the same effect, even in the interaction with the active site of both enzymes. 
Table 1. Monoamine oxidase inhibitory activity of compounds $(R, S)-\mathbf{4 a},(S)-\mathbf{4 a},(R)-\mathbf{4 a},(R, S)$ 5a, $(S)-5 \mathbf{a},(R)-5 \mathbf{a},(R, S)-6 \mathbf{a},(S)-6 \mathbf{a},(R)-6 \mathbf{a},(R, S)-4 \mathbf{c},(R, S)-4 \mathbf{d},(R, S)-4 \mathbf{e}^{\mathrm{a}}$

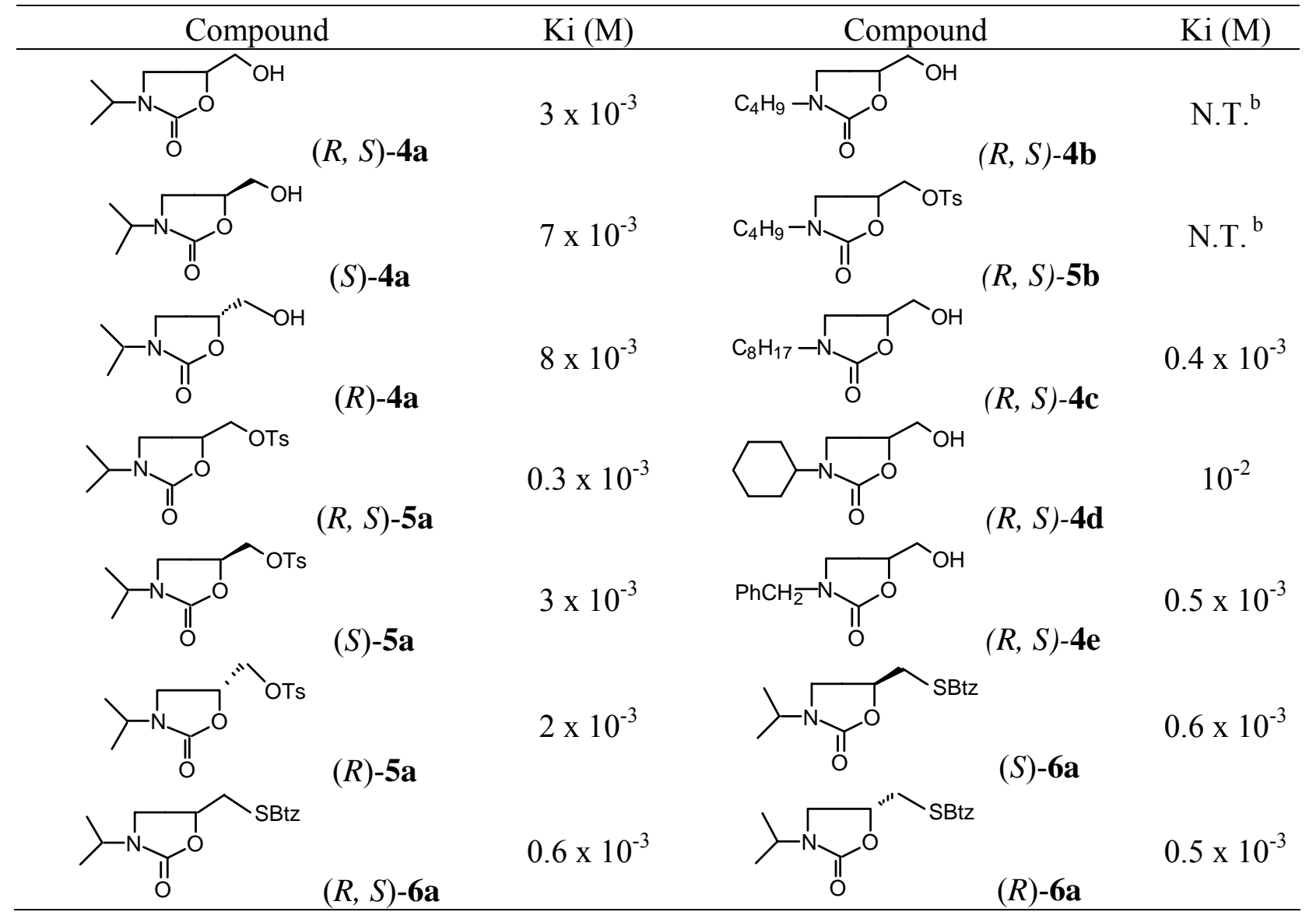

${ }^{\mathrm{a}}$ Data represent mean values of at least three separate experiments.

${ }^{\mathrm{b}}$ N.T. $=$ not tested.

Beside, $\mathrm{Ki}$ values of $(R, S)-\mathbf{6 a}$ and $(R, S)-\mathbf{4 e}$ were the same for both enzymes: $\mathrm{Ki}=2.3 \cdot 10^{-3} \mathrm{M}$ (MAO-A) and $\mathrm{Ki}=10^{-3} \mathrm{M}(\mathrm{MAO}-\mathrm{B})$, respectively, hence the two compounds showed no selectivity MAO-A/MAO-B. Furthermore, $(R, S)-\mathbf{5 a},(R, S)-\mathbf{6 a},(R)-\mathbf{6 a},(S)-\mathbf{6 a},(R, S)-\mathbf{4} \mathbf{c}$ and $4 \mathbf{e}$ have $\mathrm{IC}_{50}=1 \mathrm{mM}$, whereas the remaining tested compounds (Table 1) have $\mathrm{IC}_{50}$ values higher than $1 \mathrm{mM}$.

Finally, among all the tested compounds resulted ten-fold more active those ones bearing an aromatic group either bonded to the ring (phenyl of the N-benzyl derivative 4e) or to the side chain.

In conclusion, the results reported and discussed above, definitely prove that $\mathrm{N}_{3}$-aryl moiety is an indispensable structural requirement of the oxazolidinone class compounds to be potent MAOIs. 


\section{Experimental Section}

General Procedures. Melting points were taken on Electrothermal apparatus and are uncorrected. ${ }^{1} \mathrm{H}$ NMR spectra were recorded in $\mathrm{CDCl}_{3}$ and in $\mathrm{DMSO}-\mathrm{d}_{6}$ on a Varian EM 390 or XL200 spectrometer and chemical shifts are reported in parts per million $(\delta)$ from internal $\mathrm{Me}_{4} \mathrm{Si}$. Absolute values of the coupling constant $(J)$ are reported. IR spectra were recorded on a Perkin-Elmer 681 spectrometer. GC analyses were performed by using a HP1 column (methyl silicone gum; $5 \mathrm{~m} \times 0.53 \mathrm{~mm} \times 2.65 \mu \mathrm{m}$ film thickness) on a HP 5890 model, Series II. Optical rotations measurements were obtained using a Perkin-Elmer digital polarimeter, model $241 \mathrm{MC}$. Thin layer chromatography (TLC) was performed on silica gel sheets with fluorescent indicator (Statocrom SIF, Carlo Erba), the spots on the TLC were observed under ultraviolet light or were visualised with $\mathrm{I}_{2}$ vapour. Flash chromatography was conducted by using silica gel with an average particle size of $60 \mu \mathrm{m}$, a particle size distribution of 40-63 $\mu \mathrm{m}$ and 230-400 ASTM. GCMS analyses were performed on a HP 5995C model and microanalyses on an Elemental Analyser 1106-Carlo Erba - instrument. Chemicals and solvents were of the highest quality grade available and purchased from the Aldrich Chemical Co. or the Sigma Chemical Co.

Biological evaluation procedure: preparation of brain mitochondria and amine oxidase assay

Bovine brain mitochondria, containing MAO-A and B, were isolated according to Basford. ${ }^{17}$ Enzyme activity was determined by fluorimetric method with kynuramine as substrate. ${ }^{18}$

Compounds dissolved in dimethylsulfoxide (DMSO) were added to the reaction in the presence of kynuramine and then incubated $30 \mathrm{~min}$ at $37^{\circ} \mathrm{C}$ in a thermostated bath for enzyme activity determination.

General procedure for the preparation of 3-(alkylamino)propane-1,2-diols 3a-e $\mathrm{N}$-Alkylamine $(60.94 \mathrm{mmol})$ was dissolved in EtOH $(10 \mathrm{~mL})$ and 1-hydroxy-2,3-epoxypropane $(55.4 \mathrm{mmol})$ was slowly added. The mixture was stirred at $25^{\circ} \mathrm{C}$ for $3 \mathrm{~h}$ and ethanol evaporated under reduced pressure to afford a colourless oil (yields 85-90\%).

$(\boldsymbol{R}, \boldsymbol{S})$-3-(Isopropylamino)propane-1,2-diol (3a). ${ }^{19} \mathrm{IR}\left(\mathrm{CHCl}_{3}\right): 3500-3100,2966,1468,1340$, 1243, 1176, $1047 \mathrm{~cm}^{-1} .{ }^{1} \mathrm{H}$ NMR (DMSO-d 6 , $\left.\delta\right): 0.92-0.94\left(\mathrm{~d}, \mathrm{~J}=6.26 \mathrm{~Hz}, 3 \mathrm{H},\left(\mathrm{CH}_{3}\right)_{2} \mathrm{CH}\right) ; 0.93-$ $0.95\left(\mathrm{~d}, \mathrm{~J}=6.26 \mathrm{~Hz}, 3 \mathrm{H},\left(\mathrm{CH}_{3}\right)_{2} \mathrm{CH}\right) ; 2.19-2.26\left(\mathrm{dd}, \mathrm{J}=13.18 \mathrm{~Hz}\right.$ and $\left.7.55 \mathrm{~Hz}, 1 \mathrm{H}, \mathrm{CH}_{2} \mathrm{~N}\right) ; 2.33-$ $2.39\left(\mathrm{dd}, \mathrm{J}=11.46 \mathrm{~Hz}\right.$ and $\left.7.21 \mathrm{~Hz}, 1 \mathrm{H}, \mathrm{CH}_{2} \mathrm{OH}\right) ; 2.39-2.45(\mathrm{dd}, \mathrm{J}=13.18 \mathrm{~Hz}$ and $4.95 \mathrm{~Hz}, 1 \mathrm{H}$, $\left.\mathrm{CH}_{2} \mathrm{~N}\right) ; 2.54-2.59\left(\mathrm{dd}, \mathrm{J}=11.46 \mathrm{~Hz}\right.$ and $\left.4.32 \mathrm{~Hz}, 1 \mathrm{H}, \mathrm{CH}_{2} \mathrm{OH}\right) ; 2.84-2.92$ (heptet, $\mathrm{J}=6.26 \mathrm{~Hz}, 1 \mathrm{H}$, $\left.\left(\mathrm{CH}_{3}\right)_{2} \mathrm{CH}\right) ; 3.36-3.50$ (bs, $1 \mathrm{H}, \mathrm{NH}$ : exchange with $\mathrm{D}_{2} \mathrm{O}$, partially overlapped to a multiplet due to a $1 \mathrm{H}$ of $\mathrm{CHOH}) ; 4.30-4.60\left(\mathrm{bs}, 2 \mathrm{H}, \mathrm{CH}_{2} \mathrm{OH}\right.$ and $\mathrm{CHOH}$ : exchange with $\left.\mathrm{D}_{2} \mathrm{O}\right)$. GC-MS $(70 \mathrm{eV}) \mathrm{m} / \mathrm{z}$ (rel. int.): $133\left(\mathrm{M}^{+}, 1\right), 118$ (11), 102 (12), 72 (100), 60 (22), 56 (16), 44 (13), 43 (18), 42 (10).

(R)-(+)-3-(Isopropylamino)propane-1,2-diol. ${ }^{19}[\alpha]_{\mathrm{D}}{ }^{20}=+26,58$ (c 1, $\left.\mathrm{CH}_{3} \mathrm{OH}\right)$. Spectroscopic and analytical data were identical to those ones reported above for the racemic compound. 
(S)-(-)-3-(Isopropylamino)propane-1,2-diol. ${ }^{19,20}[\alpha]_{\mathrm{D}}{ }^{20}=-29,81$ (c 1.4, $\mathrm{CH}_{3} \mathrm{OH}$ ). Spectroscopic and analytical data were identical to those ones reported above for the racemic compound.

$(\boldsymbol{R}, \boldsymbol{S})$-3-(Butylamino)propane-1,2-diol (3b). ${ }^{21} \mathrm{IR}\left(\mathrm{CHCl}_{3}\right)$ : 3664, 3500-3100, 2913, 1460, $1351,1123 \mathrm{~cm}^{-1} .{ }^{1} \mathrm{H}$ NMR $\left(\mathrm{CDCl}_{3}, \delta\right): 0.83-0.88\left(\mathrm{t}, \mathrm{J}=7.20 \mathrm{~Hz}, 3 \mathrm{H}, \mathrm{CH}_{3}\right) ; 1.13-1.50(\mathrm{~m}, 6 \mathrm{H}$, $\left.\mathrm{CH}_{3}\left(\mathrm{CH}_{2}\right)_{3}\right) ; 2.38-2.65\left(\mathrm{~m}, 2 \mathrm{H}, \mathrm{CH}_{2} \mathrm{NHCH}_{2}\right) ; 3.38-3.63\left(\mathrm{~m}, 2 \mathrm{H}, \mathrm{CH}_{2} \mathrm{OH}\right) ; 3.65-3.74(\mathrm{~m}, 1 \mathrm{H}$, $\mathrm{CHOH})$; 4.00-4.30 (bs, 3H, $\mathrm{NHCH}_{2} \mathrm{CH}(\mathrm{OH}) \mathrm{CH}_{2} \mathrm{OH}$ : exchange with $\left.\mathrm{D}_{2} \mathrm{O}\right)$. GC-MS $(70 \mathrm{eV}) \mathrm{m} / \mathrm{z}$ (rel. int.): $147\left(\mathrm{M}^{+}, 1\right), 132$ (1), 116 (14), 104 (10), 86 (89), 57 (13), 44 (100).

(R, S)-3-(Octylamino)propane-1,2-diol (3c). ${ }^{21} \mathrm{IR}\left(\mathrm{CHCl}_{3}\right): 3668,3500-3200,2993,2927,1460$, 1378, $1323 \mathrm{~cm}^{-1} .{ }^{1} \mathrm{H}$ NMR $\left(\mathrm{CDCl}_{3}, \delta\right): 0.84-0.89\left(\mathrm{t}, \mathrm{J}=6.59 \mathrm{~Hz}, 3 \mathrm{H}, \mathrm{CH}_{3} \mathrm{CH}_{2}\right) ; 1.18-1.34(\mathrm{~m}$, $\left.12 \mathrm{H}, \mathrm{CH}_{3}\left(\mathrm{CH}_{2}\right)_{6} \mathrm{CH}_{2}\right) ; 1.36-1.52\left(\mathrm{~m}, 2 \mathrm{H}, \mathrm{CH}_{2} \mathrm{NH}\right) ; 2.40-2.70(\mathrm{~m}, 1 \mathrm{H}, \mathrm{NHCHHCHOH}$, overlapped to a bs, $1 \mathrm{H}, \mathrm{NH}$ : exchange with $\left.\mathrm{D}_{2} \mathrm{O}\right) ; 2.72-2.78(\mathrm{dd}, \mathrm{J}=12.08 \mathrm{~Hz}$ and $3.84 \mathrm{~Hz}, 1 \mathrm{H}$, $\mathrm{NHCHHCHOH}) ; 2.95-3.40$ (bs, $2 \mathrm{H}, \mathrm{OH}$ : exchange with $\left.\mathrm{D}_{2} \mathrm{O}\right) ; 3.53-3.59$ (dd, J= $11.26 \mathrm{~Hz}$ and $5.22 \mathrm{~Hz}, 1 \mathrm{H}, \mathrm{CHHOH}) ; 3.64-3.69(\mathrm{dd}, \mathrm{J}=11.26 \mathrm{~Hz}$ and $3.71 \mathrm{~Hz}, 1 \mathrm{H}, \mathrm{CHHOH}) ; 3.45-3.78(\mathrm{~m}, 1 \mathrm{H}$, $\left.\mathrm{CH}_{2} \mathrm{CHOH}\right)$. GC-MS (70 eV) m/z (rel. int.): $203\left(\mathrm{M}^{+}, 1\right), 142$ (100), 128 (6), 75 (12), 44 (95).

(R, S)-3-(Cyclohexylamino)propane-1,2-diol (3d). ${ }^{22} \mathrm{IR}\left(\mathrm{CHCl}_{3}\right): 3666,3500-3200,2926,2820$, 1457, 1350, 1321, $1106 \mathrm{~cm}^{-1} .{ }^{1} \mathrm{H}$ NMR $\left(\mathrm{CDCl}_{3}, \delta\right): 0.95-1.30\left(\mathrm{~m}, 6 \mathrm{H},\left(\mathrm{CH}_{2}\right)_{3}\right.$ of the cyclohexyl); 1.50-1.88 (m, $4 \mathrm{H},\left(\mathrm{CH}_{2}\right)_{2}$ of the cyclohexyl); 2.25-2.45 (m, 1H, CH of the cyclohexyl); 2.50-2.70 (bs, $1 \mathrm{H}, \mathrm{NH}$ : exchange with $\mathrm{D}_{2} \mathrm{O}$; partially overlapped to a multiplet, $\left.1 \mathrm{H}, \mathrm{NHCHHCHOH}\right) ; 2.73-$ $2.78(\mathrm{dd}, \mathrm{J}=11.95 \mathrm{~Hz}$ and $3.70 \mathrm{~Hz}, 1 \mathrm{H}, \mathrm{NHCHHCHOH}) ; 3.40-3.78$ (bs, 2H, OH: exchange with $\mathrm{D}_{2} \mathrm{O}$, partially overlapped to a multiplet due to $3 \mathrm{H}: 2 \mathrm{H}$ for $\mathrm{CH}_{2} \mathrm{OH}$ and $1 \mathrm{H}$ for $\mathrm{HOCHCH}_{2} \mathrm{OH}$ ). GC-MS (70 eV) m/z (rel. int.): $173\left(\mathrm{M}^{+}, 1\right), 112$ (100), 83 (5), 32 (15).

$(\boldsymbol{R}, \boldsymbol{S})$-3-(Benzylamino)propane-1,2-diol (3e). ${ }^{23} \mathrm{IR}\left(\mathrm{CHCl}_{3}\right): 3665,3500-3200,3050,2927$, $2841,1603,1456,1351,1323,1110,972,900,865 \mathrm{~cm}^{-1} .{ }^{1} \mathrm{H} \mathrm{NMR}\left(\mathrm{CDCl}_{3}, \delta\right): 2.50-2.70$ (m, 2H, $\mathrm{CH}_{2} \mathrm{NH}$ ); 3.30-3.85 (m, 5H: $3 \mathrm{H}, \mathrm{CH}_{2} \mathrm{CHOH}$ and $2 \mathrm{H}, \mathrm{PhCH}_{2}$ ); 3.90-4.20 (bs, 3H, $\mathrm{NHCH}_{2}$, $\mathrm{CH}_{2} \mathrm{CHOH}$ and $\mathrm{CH}_{2} \mathrm{OH}$ : exchange with $\left.\mathrm{D}_{2} \mathrm{O}\right) ; 7.20-7.40(\mathrm{~m}, 5 \mathrm{H}$, aromatic protons). GC-MS (70 eV) m/z (rel. int.): $181\left(\mathrm{M}^{+}, 1\right), 120$ (65), 106 (12), 91 (100).

General procedure for the preparation of 3-alkyl-5-(hydroxymethyl)-1,3-oxazolidin-2-ones $(4 a-e)^{24}$

A mixture of 3-(alkylamino)-1,2-propanediol (54 mmol), diethylcarbonate $(59.5 \mathrm{mmol})$ and anhydrous sodium methoxide $(5.5 \mathrm{mmol})$ was stirred under reflux for $4 \mathrm{~h}$. After cooling at room temperature the reaction mixture was evaporated under reduced pressure to afford an oil. The residue oil was treated with ethyl acetate and the obtained solution was washed with water. The organic layer was dried $\left(\mathrm{Na}_{2} \mathrm{SO}_{4}\right)$ and concentrated under reduced pressure obtaining a yellow oil purified by chromatography (silica gel, eluent: petroleum ether: ethyl acetate $=7: 3$ ). The product was isolated as white crystals (yields 30-40\%).

( $R, S)$-3-Isopropyl-5-(hydroxymethyl)-1,3-oxazolidin-2-one (4a). M.p. $54-55{ }^{\circ} \mathrm{C} . \mathrm{IR}\left(\mathrm{CHCl}_{3}\right)$ : 3500-3200, 2974, 1732, 1440, 1371, 1264, $1048 \mathrm{~cm}^{-1} .{ }^{1} \mathrm{H}$ NMR $\left(\mathrm{CDCl}_{3}, \delta\right): 1.13-1.15(\mathrm{~d}, \mathrm{~J}=$ $\left.6.73 \mathrm{~Hz}, 3 \mathrm{H},\left(\mathrm{CH}_{3}\right)_{2} \mathrm{CH}\right) ; 1.14-1.16\left(\mathrm{~d}, \mathrm{~J}=6.73 \mathrm{~Hz}, 3 \mathrm{H},\left(\mathrm{CH}_{3}\right)_{2} \mathrm{CH}\right) ; 3.36-3.41(\mathrm{dd}, \mathrm{J}=8.44 \mathrm{~Hz}$ and $6.66 \mathrm{~Hz}, 1 \mathrm{H}, \mathrm{CHHN}) ; 3.46-3.52(\mathrm{t}, \mathrm{J}=8.44 \mathrm{~Hz}, 1 \mathrm{H}, \mathrm{CHHN}) ; 3.39-3.52$ (bs, $1 \mathrm{H}, \mathrm{CH}_{2} \mathrm{OH}$ : exchange with $\left.\mathrm{D}_{2} \mathrm{O}\right) ; 3.59-3.66(\mathrm{~m}, 1 \mathrm{H}, \mathrm{CHHOH}) ; 3.79-3.86(\mathrm{~m}, 1 \mathrm{H}, \mathrm{CHHOH}) ; 3.99-4.09$ 
(heptet, $\left.\mathrm{J}=6.73 \mathrm{~Hz}, 1 \mathrm{H},\left(\mathrm{CH}_{3}\right)_{2} \mathrm{CH}\right) ; 4.52-4.60\left(\mathrm{~m}, 1 \mathrm{H}, \mathrm{CHOCH}_{2} \mathrm{OH}\right) .{ }^{13} \mathrm{C} \mathrm{NMR}\left(\mathrm{CDCl}_{3}, \delta\right)$ : 19.76, 20.04, 41.04, 45.02, 63.19, 73.86, 157.58. GC-MS (70 eV) m/z (rel. int.): $159\left(\mathrm{M}^{+}, 4\right), 144$ (100), 86 (22), 70 (25), 58 (15), 56 (61), 43 (32), 42 (11), 41 (14).

(R)-(-)-3-Isopropyl-5-(hydroxymethyl)-1,3-oxazolidin-2-one. ${ }^{25}[\alpha]_{\mathrm{D}}{ }^{20}=-43.54$ (c $\left.1, \mathrm{CH}_{3} \mathrm{OH}\right)$. Spectroscopic and analytical data were identical to those ones reported above for the racemic compound.

(S)-(+)-3-Isopropyl-5-(hydroxymethyl)-1,3-oxazolidin-2-one. ${ }^{25}[\alpha]_{\mathrm{D}}{ }^{20}=+48.29$ (c 1.2, $\mathrm{CHCl}_{3}$ ). Spectroscopic and analytical data were identical to those ones reported above for the racemic compound.

(R, S)-3-Butyl-5-(hydroxymethyl)-1,3-oxazolidin-2-one (4b). IR $\left(\mathrm{CHCl}_{3}\right)$ : 3593, 3550-3200, 2934, 1737, 1490, 1456, 1375, 1272, $1046 \mathrm{~cm}^{-1} .{ }^{1} \mathrm{H} \mathrm{NMR}\left(\mathrm{CDCl}_{3}, \delta\right): 0.86-0.91$ (t, J= 7.32Hz, $3 \mathrm{H}, \mathrm{CH}_{3} \mathrm{CH}_{2}$ ); 1.23-1.35 (sextet, $2 \mathrm{H}, \mathrm{J}=7.32 \mathrm{~Hz}, \mathrm{CH}_{3} \mathrm{CH}_{2} \mathrm{CH}_{2}$ ), 1.43-1.53 (quintet, $\mathrm{J}=7.32 \mathrm{~Hz}$, $2 \mathrm{H}, \mathrm{CH}_{3} \mathrm{CH}_{2} \mathrm{CH}_{2} \mathrm{CH}_{2}$ ); 2.30-2.80 (bs, $1 \mathrm{H}, \mathrm{OH}$ : exchange with $\left.\mathrm{D}_{2} \mathrm{O}\right) ; 3.16-3.22(\mathrm{~m}, 2 \mathrm{H}$, $\left.\mathrm{CH}_{2} \mathrm{CH}_{2} \mathrm{~N}\right) ; 3.39-3.44(\mathrm{dd}, \mathrm{J}=8.86 \mathrm{~Hz}$ and $6.71 \mathrm{~Hz}, 1 \mathrm{H}, \mathrm{NCHHCHO}) ; 3.50-3.56(\mathrm{t}, \mathrm{J}=8.86 \mathrm{~Hz}$, $1 \mathrm{H}, \mathrm{NCHHCHO}) ; 3.57-3.62(\mathrm{dd}, \mathrm{J}=12.29 \mathrm{~Hz}$ and $4.19 \mathrm{~Hz}, 1 \mathrm{H}, \mathrm{CHCHHOH}) ; 3.77-3.82(\mathrm{dd}, \mathrm{J}=$ $12.29 \mathrm{~Hz}$ and $3.28 \mathrm{~Hz}, 1 \mathrm{H}, \mathrm{CHCHHOH}) ; 4.50-4.58\left(\mathrm{~m}, 1 \mathrm{H}, \mathrm{CH}_{2} \mathrm{CHCH}_{2} \mathrm{OH}\right) .{ }^{13} \mathrm{C} \mathrm{NMR}\left(\mathrm{CDCl}_{3}\right.$, $\delta): 13.87,19.95,29.44,43.94,45.83,63.04,73.75,158.44$. GC-MS (70 eV) m/z (rel. int.): 173 $\left(\mathrm{M}^{+}, 6\right), 142$ (10), 130 (71), 116 (3), 86 (21), 57 (26), 56 (20), 44 (51), 42 (100), 31 (15). Anal. calcd for $\mathrm{C}_{8} \mathrm{H}_{15} \mathrm{NO}_{3}$ : C, 55.49; H, 8.67; N, 8.09. Found: C, 55.47; H, 8.68; N, 8.10.

$(\boldsymbol{R}, \boldsymbol{S})$-3-Octyl-5-(hydroxymethyl)-1,3-oxazolidin-2-one (4c). IR $\left(\mathrm{CHCl}_{3}\right)$ : 3665, 3550-3200, 2930, 1745, 1490, 1455, 1346, 1104, $908 \mathrm{~cm}^{-1} .{ }^{1} \mathrm{H} \mathrm{NMR}\left(\mathrm{CDCl}_{3}, \delta\right): 0.82-0.86(\mathrm{t}, \mathrm{J}=6.46 \mathrm{~Hz}, 3 \mathrm{H}$, $\left.\mathrm{CH}_{3} \mathrm{CH}_{2}\right)$; $1.10-1.38\left(\mathrm{~m}, 10 \mathrm{H}, \mathrm{CH}_{3}\left(\mathrm{CH}_{2}\right)_{5} \mathrm{CH}_{2} \mathrm{CH}_{2}\right) ; 1.40-1.56\left(\mathrm{~m}, 2 \mathrm{H}, \mathrm{CH}_{3}\left(\mathrm{CH}_{2}\right)_{5} \mathrm{CH}_{2} \mathrm{CH}_{2}\right)$; 2.20-2.60 (bs, $1 \mathrm{H}, \mathrm{OH}$ : exchange with $\left.\mathrm{D}_{2} \mathrm{O}\right)$; 3.11-3.29 (m, $\left.2 \mathrm{H}, \mathrm{CH}_{2} \mathrm{~N}\right) ; 3.40-3.45(\mathrm{dd}, \mathrm{J}=8.38 \mathrm{~Hz}$ and $6.73 \mathrm{~Hz}, 1 \mathrm{H}, \mathrm{NCHHCHO}) ; 3.51-3.57(\mathrm{t}, \mathrm{J}=8.38 \mathrm{~Hz}, 1 \mathrm{H}, \mathrm{NCHHCHO}) ; 3.58-3.64(\mathrm{dd}, \mathrm{J}=$ $12.40 \mathrm{~Hz}$ and $4.25 \mathrm{~Hz}, 1 \mathrm{H}, \mathrm{CHCHHOH}) ; 3.80-3.85(\mathrm{dd}, \mathrm{J}=12.40 \mathrm{~Hz}$ and $3.02 \mathrm{~Hz}, 1 \mathrm{H}$,

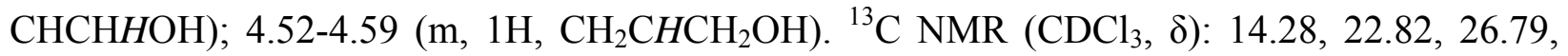
27.43, 29.38, 31.95, 44.30, 45.80, 63.09, 73.71, 158.36. GC-MS (70 eV) m/z (rel. int.): 229 (M 8), 184 (45), 158 (8), 130 (100), 86 (12), 56 (20), 42 (89). Anal. calcd for $\mathrm{C}_{12} \mathrm{H}_{23} \mathrm{NO}_{3}$ : C, 62.88; H, 10.04; N, 6.11. Found: C, 62.85; H, 10.03; N, 6.10.

$(\boldsymbol{R}, \boldsymbol{S})$-3-Cyclohexyl-5-(hydroxymethyl)-1,3-oxazolidin-2-one (4d). IR $\left(\mathrm{CHCl}_{3}\right)$ : 3650, 35003200, 2927, 1740, 1488, 1453, 1377, 1105, $997 \mathrm{~cm}^{-1} .{ }^{1} \mathrm{H}$ NMR $\left(\mathrm{CDCl}_{3}, \delta\right): 1.05-1.42(\mathrm{~m}, 6 \mathrm{H}$, $\left(\mathrm{CH}_{2}\right)_{3}$ of cyclohexyl ring), 1.63-1.90 (m, $4 \mathrm{H},\left(\mathrm{CH}_{2}\right)_{2}$ of cyclohexyl ring); 2.52-2.65 $90(\mathrm{~m}, 1 \mathrm{H}$, $\mathrm{CH}$ of cyclohexyl ring); $3.38-3.43\left(\mathrm{dd}, \mathrm{J}=8.38 \mathrm{~Hz}\right.$ and $\left.6.86 \mathrm{~Hz}, 1 \mathrm{H}, \mathrm{NCHHCHCH}_{2} \mathrm{OH}\right) ; 3.49-$ $3.55\left(\mathrm{t}, \mathrm{J}=8.38 \mathrm{~Hz}, 1 \mathrm{H}, \mathrm{NCHHCHCH} \mathrm{H}_{2} \mathrm{OH}\right.$ ); 3.61-3.65 (not well resolved dd to precisely determine the coupling constants, $1 \mathrm{H}, \mathrm{CHCHHOH}$ overlapped to a bs, $1 \mathrm{H} \mathrm{OH}$ : exchange with $\left.\mathrm{D}_{2} \mathrm{O}\right)$; 3.79-3.85 (m, 1H, CHCHHOH); 4.52-4.62 (m, $\left.1 \mathrm{H}, \mathrm{NCH}_{2} \mathrm{CHCH}_{2} \mathrm{OH}\right) .{ }^{13} \mathrm{C} \mathrm{NMR}\left(\mathrm{CDCl}_{3}\right.$, $\delta): 25.51,29.90,30.27,30.58,41.96,63.43,73.72,75.53,157.39$. GC-MS (70 eV) m/z (rel. int.): 199 (M+, 25), 156 (100), 118 (62), 83 (23), 82 (24), 68 (26), 56 (13), 55 (34), 54 (11), 41 (24). Anal. calcd for $\mathrm{C}_{10} \mathrm{H}_{17} \mathrm{NO}_{3}$ : C, 60.30; H, 8.54; N, 7.03. Found: C, 60.31; H, 8.58; N, 7.05.

(R, S)-3-Benzyl-5-(hydroxymethyl)-1,3-oxazolidin-2-one (4e). ${ }^{26} \mathrm{IR}\left(\mathrm{CHCl}_{3}\right): 3664,3500-3200$, 3020, 2928, 1746, 1490, 1455, 1345, 1103, 907, $865 \mathrm{~cm}^{-1} .{ }^{1} \mathrm{H}$ NMR $\left(\mathrm{CDCl}_{3}, \delta\right): 3.00-3.30$ (bs, 
1H, OH: exchange with $\left.\mathrm{D}_{2} \mathrm{O}\right) ; 3.31-3.36(\mathrm{dd}, \mathrm{J}=8.38 \mathrm{~Hz}$ and $6.87 \mathrm{~Hz}, 1 \mathrm{H}, \mathrm{NCHHCHO}) ; 3.40-$ $3.45(\mathrm{t}, \mathrm{J}=8.38 \mathrm{~Hz}, 1 \mathrm{H}, \mathrm{NCHHCHO}) ; 3.56-3.62(\mathrm{dd}, \mathrm{J}=12.58 \mathrm{~Hz}$ and $4.26 \mathrm{~Hz}, 1 \mathrm{H}, \mathrm{CHCHHOH})$; $3.79-3.85(\mathrm{dd}, \mathrm{J}=12.58 \mathrm{~Hz}$ and $3.02 \mathrm{~Hz}, 1 \mathrm{H}, \mathrm{CHCHHOH}) ; 4.33-4.38(\mathrm{~d}, \mathrm{~J}=15.04 \mathrm{~Hz}, 1 \mathrm{H}$, $\left.\mathrm{C}_{6} \mathrm{H}_{4} \mathrm{CHHN}\right)$; 4.44-4.49 (d, J=15.04Hz, $\left.1 \mathrm{H}, \mathrm{C}_{6} \mathrm{H}_{4} \mathrm{CHHN}\right)$; 4.52-4.59 (m, 1H, $\left.\mathrm{CH}_{2} \mathrm{CHCH}_{2} \mathrm{OH}\right)$; 7.25-7.38 (m, 5H, aromatic protons). ${ }^{13} \mathrm{C} \mathrm{NMR}\left(\mathrm{CDCl}_{3}, \delta\right): 45.39,48.47,63.14,73.92,128.19$, 128.25, 128.30, 129.07, 135.77, 158.44. GC-MS (70 eV) m/z (rel. int.): $207\left(\mathrm{M}^{+}, 23\right), 176$ (5), 162 (9), 104 (20), 91 (100), 79 (8), 65 (18), 31 (10).

$(\boldsymbol{R}, \boldsymbol{S})$-3-Isopropyl -5-toluenesulfonyloxymethyloxazolidin-2-one (5a). ${ }^{27}$ To a solution of ( $R$, S)-5-hydroxymethyl-3-isopropyloxazolidin-2-one $(1.72 \mathrm{~g}, 10.8 \mathrm{mmol})$ in $\mathrm{CHCl}_{3}(10 \mathrm{~mL})$ was added $p$-toluenesolfonyl chloride $(2.67 \mathrm{~g}, 14 \mathrm{mmol})$ and pyridine $(16.5 \mathrm{mmol})$. The mixture was stirred at room temperature for $16 \mathrm{~h}$, and then quenched with $\mathrm{H}_{2} \mathrm{O}$ and diluted with $\mathrm{CHCl}_{3}$. The organic layer was washed with $1 \mathrm{~N} \mathrm{HCl}$, then with $10 \% \mathrm{NaHCO}_{3}$, dried over anhydrous $\mathrm{Na}_{2} \mathrm{SO}_{4}$ and evaporated to dryness. The pure product was obtained as white solid in $83 \%$ yield by crystallization (petroleum ether:ethyl acetate $=20: 1$ ). $\mathrm{Mp} 77-78^{\circ} \mathrm{C} . \mathrm{IR}\left(\mathrm{CHCl}_{3}\right)$ : 3030, 2955, 1750, 1599, 1438, 1371, 1176, 996, 970, 867, $833 \mathrm{~cm}^{-1} .{ }^{1} \mathrm{H}$ NMR $\left(\mathrm{CDCl}_{3}, \delta\right): 1.10-1.12$ (d, J= $\left.6.87 \mathrm{~Hz}, 3 \mathrm{H},\left(\mathrm{CH}_{3}\right)_{2} \mathrm{CH}\right) ; 1.12-1.14\left(\mathrm{~d}, \mathrm{~J}=6.87 \mathrm{~Hz}, 3 \mathrm{H},\left(\mathrm{CH}_{3}\right)_{2} \mathrm{CH}\right) ; 2.43\left(\mathrm{~s}, 3 \mathrm{H}, \mathrm{CH}_{3} \mathrm{C}_{6} \mathrm{H}_{4}\right) ; 3.30-$ $3.35(\mathrm{dd}, \mathrm{J}=9.00 \mathrm{~Hz}$ and $5.56 \mathrm{~Hz}, 1 \mathrm{~Hz}, \mathrm{CHHN}) ; 3.53-3.59(\mathrm{t}, \mathrm{J}=9.00 \mathrm{~Hz}, 1 \mathrm{H}, \mathrm{CHHN}) ; 3.98-4.07$ (heptet, $\left.\mathrm{J}=6.87 \mathrm{~Hz}, 1 \mathrm{H},\left(\mathrm{CH}_{3}\right)_{2} \mathrm{CH}\right) ; 4.08-4.11$ (m, 2H, $\left.\mathrm{CH}_{2} \mathrm{OTosyl}\right) ; 4.60-4.68$ (m, 1H, $\left.\mathrm{CH}_{2} \mathrm{CHO}\right)$; 7.30-7.80 (m, 4H, aromatic protons). ${ }^{13} \mathrm{C} \mathrm{NMR}\left(\mathrm{CDCl}_{3}, \delta\right): 19.82,19.89,21.91$, 41.42, 45.12, 69.03, 69.89, 128.21, 130.32, 132.28, 145.75, 156.30. GC-MS (70 eV) m/z (rel. int.): 313 ( $\left.\mathrm{M}^{+}, 9\right), 299$ (13), 298 (77), 155 (51), 141 (9), 98 (37), 97 (27), 92 (15), 91 (86), 86 (19), 85 (31), 82 (100), 70 (16), 65 (22), 56 (21), 43 (25), 42 (16), 41 (15).

(R)-(-)-3-Isopropyl -5-toluenesulfonyloxymethyloxazolidin-2-one. ${ }^{27}$ It was prepared by the same procedure used as for $(R, S)$-5a, but starting from $(R)$-5-hydroxymethyl-3isopropyloxazolidin-2-one. Yield $75 \% .[\alpha]_{\mathrm{D}}{ }^{20}=-49.19$ (c 1, $\mathrm{CHCl}_{3}$ ). Spectroscopic and analytical data were identical to those ones reported above for the racemic compound.

(S)-(+)-3-Isopropyl-5-toluenesulfonyloxymethyloxazolidin-2-one. ${ }^{27}$ It was prepared by the same procedure used as for $(R, S)$-5a, but starting from (S)-5-hydroxymethyl-3isopropyloxazolidin-2-one. Yield $80 \%$. $[\alpha]_{\mathrm{D}}{ }^{20}=+56.24\left(\mathrm{c} 1.2, \mathrm{CHCl}_{3}\right)$. Spectroscopy and analytical data were identical to those ones reported above for the racemic compound.

$(\boldsymbol{R}, \boldsymbol{S})$-3-Butyl-5-toluenesulfonyloxymethyloxazolidin-2-one (5b). To a solution of $(R, S)-5$ hydroxymethyl-3-butyloxazolidin-2-one $(0.716 \mathrm{~g}, 4.14 \mathrm{mmol})$ in $\mathrm{CHCl}_{3}$ was added $p$ toluenesulfonyl chloride $(1.8155 \mathrm{~g}, 9.52 \mathrm{mmol})$ and pyridine $(78.7 \mathrm{mmol})$. The mixture was stirred at room temperature for $18 \mathrm{~h}$. Then, the reaction was quenched with $\mathrm{H}_{2} \mathrm{O}$ and diluted with $\mathrm{CHCl}_{3}$. The organic layer was washed with $1 \mathrm{~N} \mathrm{HCl}$, then with $10 \% \mathrm{NaHCO}_{3}$, dried over anhydrous $\mathrm{Na}_{2} \mathrm{SO}_{4}$ and the solvent evaporated to dryness. The pure product was obtained as white solid (20\% yield) by crystallization (petroleum ether:ethyl acetate $=20 / 1$ ).

IR $\left(\mathrm{CHCl}_{3}\right): 3035,2928,2855,1755,1600,1455,1362,997,970,908,834 \mathrm{~cm}^{-1}$. ${ }^{1} \mathrm{H}$ NMR $\left(\mathrm{CDCl}_{3}, \delta\right): 0.88-0.93\left(\mathrm{t}, \mathrm{J}=7.28 \mathrm{~Hz}, 3 \mathrm{H}, \mathrm{CH}_{3} \mathrm{CH}_{2}\right) ; 1.22-1.38\left(\mathrm{~m}, 2 \mathrm{H}, \mathrm{CH}_{3} \mathrm{CH}_{2} \mathrm{CH}_{2}\right) ; 1.42-1.52$ (quintet, $\left.\mathrm{J}=7.28 \mathrm{~Hz}, 2 \mathrm{H}, \mathrm{CH}_{3} \mathrm{CH}_{2} \mathrm{CH}_{2} \mathrm{CH}_{2}\right) ; 2.44\left(\mathrm{~s}, 3 \mathrm{H}, \mathrm{C}_{6} \mathrm{H}_{4} \mathrm{CH}_{3}\right) ; 3.13-3.28(\mathrm{~m}, 2 \mathrm{H}$, $\left.\mathrm{CH}_{2} \mathrm{CH}_{2} \mathrm{~N}\right) ; 3.37-3.42\left(\mathrm{dd}, \mathrm{J}=8.79 \mathrm{~Hz}\right.$ and $\left.5.77 \mathrm{~Hz}, 1 \mathrm{H}, \mathrm{NCHHCHCH}{ }_{2} \mathrm{OH}\right) ; 3.58-3.64(\mathrm{t}, \mathrm{J}=$ 
$8.79 \mathrm{~Hz}, 1 \mathrm{H}, \mathrm{NCHHCHCH} 2 \mathrm{OH}) ; 4.08-4.13(\mathrm{dd}, \mathrm{J}=10.99 \mathrm{~Hz}$ and $4.67 \mathrm{~Hz}, 1 \mathrm{H}, \mathrm{CHHOTosyl})$; $4.12-4.17(\mathrm{dd}, \mathrm{J}=10.99 \mathrm{~Hz}$ and $4.26 \mathrm{~Hz}, 1 \mathrm{H}, \quad$ CHHOTosyl); 4.61-4.69 (m, $1 \mathrm{H}$, $\mathrm{CH}_{2} \mathrm{CHCH}_{2} \mathrm{OTosyl}$ ); 7.34-7.37 (m, 2H, aromatic protons); 7.76-7.78 (m, 2H, aromatic protons). ${ }^{13} \mathrm{C} \mathrm{NMR}\left(\mathrm{CDCl}_{3}, \delta\right):$ 13.77, 19.84, 21.76, 29.28, 29.83, 43.81, 45.81, 69.21, 69.88, 128.09, 130.26, 132.32, 145.62, 157.13, 171.21. GC-MS (70 eV) m/z (rel. int.): $327\left(\mathrm{M}^{+}, 5\right), 284$ (14), 172 (13), 155 (63), 112 (51), 91 (100), 68 (99), 41 (43). Anal. calcd for $\mathrm{C}_{15} \mathrm{H}_{21} \mathrm{NO}_{5} \mathrm{~S}$ : C, 55.06; H, 6.42; N, 4.28. Found: C, 55.07; H, 6.45; N, 4.26.

$(\boldsymbol{R}, \boldsymbol{S})$-5-(Benzothiazol-2-ylsulfanylmethyl)-3-isopropyloxazolidin-2-one (6a). To a solution of $(R, S)$-3-isopropyl-5-toluenesulfonyloxymethyloxazolidin-2-one in $\mathrm{MeOH}(5 \mathrm{~mL}), \mathrm{Na}_{2} \mathrm{CO}_{3}$ $(0.607 \mathrm{mmol})$ was added. A solution of 2-mercaptobenzothiazol $(1.214 \mathrm{mmol})$ in $\mathrm{MeOH}(3 \mathrm{~mL})$ was slowly added to the reaction mixture. The mixture was stirred under reflux for $8 \mathrm{~h}$; then, after cooling at room temperature, it was concentrated under reduced pressure. The resulting oil was dissolved into ethyl acetate and washed with $\mathrm{H}_{2} \mathrm{O}$. The organic layer was dried over anhydrous $\mathrm{Na}_{2} \mathrm{SO}_{4}$ and concentrated. A yellow solid was obtained by chromatography (silica gel; eluent: petroleum ether:ethyl acetate $=7 / 3$ ) (yield: 75\%).

IR $\left(\mathrm{CHCl}_{3}\right): 3030,2980,1745,1590,1370,997 \mathrm{~cm}^{-1} .{ }^{1} \mathrm{H} \mathrm{NMR}\left(\mathrm{CDCl}_{3}, \delta\right): 1.13-1.16(\mathrm{~d}, \mathrm{~J}=$ $\left.6.73 \mathrm{~Hz}, 6 \mathrm{H},\left(\mathrm{CH}_{3}\right)_{2} \mathrm{CH}\right) ; 3.39-3.44(\mathrm{dd}, 1 \mathrm{H}, \mathrm{J}=8.58 \mathrm{~Hz}$ and $6.25 \mathrm{~Hz}, \mathrm{CHHN}) ; 3.57-3.67(\mathrm{dd}, \mathrm{J}=$ $13.73 \mathrm{~Hz}$ and $7.41 \mathrm{~Hz}, 1 \mathrm{H}, \mathrm{CHHS}$; such a dd is partially overlapped to a $\mathrm{t}, \mathrm{J}=8.58 \mathrm{~Hz}, 1 \mathrm{H}$, $\mathrm{CHHN}) ; 3.76-3.83(\mathrm{dd}, \mathrm{J}=13.73 \mathrm{~Hz}$, and $5.15 \mathrm{~Hz}, 1 \mathrm{H}, \mathrm{CHHS}) ; 4.05-4.20$ (heptet, $\mathrm{J}=6.73 \mathrm{~Hz}, 1 \mathrm{H}$, $\left.\left(\mathrm{CH}_{3}\right)_{2} \mathrm{CH}\right) ; 4.88-4.97$ (m, $\left.1 \mathrm{H}, \mathrm{CH}_{2} \mathrm{CHOCO}\right) ; 7.30-7.84\left(\mathrm{~m}, 4 \mathrm{H}\right.$, aromatic protons). ${ }^{13} \mathrm{C}$ NMR $\left(\mathrm{CDCl}_{3}, \delta\right): 19.97,36.34,44.04,45.08,71.62,121.37,121.79,124.84,126.44,135.68,152.97$, 156.74, 165.20. GC-MS (70 eV) m/z (rel. int.): $308\left(\mathrm{M}^{+}, 2\right), 181$ (42), 169 (12), 168 (33), 167 (100), 148 (15), 136 (11), 122 (5), 98 (93), 82 (9), 70 (6), 56 (9), 43 (14). Anal. calcd for $\mathrm{C}_{14} \mathrm{H}_{16} \mathrm{~N}_{2} \mathrm{O}_{2} \mathrm{~S}_{2}$ : C, 54.54; H, 5.19; N, 9.09. Found: C, 54.57; H, 5.21; N, 9.11.

(R)-(+)-5-(Benzothiazol-2-ylsulfanylmethyl)-3-isopropyloxazolidin-2-one. It was prepared by the same procedure used for $(R, S)-6 a$, but starting from $(R)$-3-isopropyl-5toluenesulfonyloxymethyloxazolidin-2-one. Yield $40 \% . \quad[\alpha]_{\mathrm{D}}^{20}=+29.54$ (c $1, \mathrm{CHCl}_{3}$ ). Spectroscopic and analytical data were identical to those ones reported above for the racemic compound.

(S)-(-)-5-(Benzothiazol-2-ylsulfanylmethyl)-3-isopropyloxazolidin-2-one. It was prepared by the same procedure used for $(R, S)$-6a, but starting from (S)-3-isopropyl-5toluenesulfonyloxymethyloxazolidin-2-one. Yield 28\%. $[\alpha]_{\mathrm{D}}{ }^{20}=-32.82$ (c 1.1, $\mathrm{CHCl}_{3}$ ). Spectroscopic and analytical data were identical to those ones reported above for the racemic compound. 


\section{Acknowledgments}

This work was supported by Ministero dell'Istruzione, dell'Università e della Ricerca (MIUR) and University of Bari. Thanks are due to Dr. Peppino Di Cunto for having carried out the synthesis of some compounds.

\section{References}

1. Goodman Gilman, A.; Rall, T. W.; Nies, A. S.; Taylor, P. In Goodman and Gilman's The Pharmacological Basis of Therapeutics, IX Edn; Pergamon Press: McGraw- Hill: New York, 1995.

2. Kalgutkar, A.S.; Dalvie, D. K.; Castagnoli, N. Jr.; Taylor, T. Chem. Res. Toxicol. 2001, 14, 1139.

3. Feenstra, R.; Ronken, E.; Koopman, T.; De Vries, M.; McCreary, A.; Stoker, M.; Van Charldorp, K.; Long, S.; Van Scharrenburg, G. Drugs of the Future 2001, 26, 128.

4. Kyburz, E. DN\&P 1990, 3, 592.

5. Rajeeshri, G.; Vital, M. Bioorg. Med. Chem. 2001, 9, 3153.

6. Chi Sing, L.; Allwinw, D. A.; Barbachin, M. R.; Grega, K. C.; Dolak, L. A.; Ford, C. W.; Jensen, R. M.; Seest, E. P.; Hamel, J. C.; Schadt, R. D.; Stapert, D.; Yagi, B. H.; Zurengo, G. E.; Genin, M. J. Bioorg. Med. Chem. 2001, 9, 3243.

7. Eustice, D. C.; Feldman, P. A.; Slee, A. M. Biochem. Biophs. Res. Commun. 1988, 150, 965.

8. Eustice, D. C.; Feldman, P. A.; Zajac, I.; Slee, A. M. Antimicrob. Agents Chemother. 1982, 32, 1218.

9. Mai, A.; Artico, M.; Esposito, M.; Ragno, G.; Sbardella, G.; Massa, S. Il Farmaco 2003, 58, 231.

10. Gates, K. S.; Silverman, R. B. J. Am. Chem. Soc. 1990, 112, 9364.

11. Wermuth, C. G. In The Practice of Medicinal Chemistry; Wermuth, C. G., Ed.; Academic Press, 1996, Part III; p 303.

12. Tsuda, Y.; Yoshimoto, K.; Nishikawa, T. Chem. Pharm. Bull. 1981, 29, 3593.

13. Dirlam, N. L.; Moore, B. S.; Urban, F. J. J. Org. Chem. 1982, 52, 3587.

14. Delaunay, D.; Le Corre, M. J. Chem. Soc., Perkin Trans. 1994, I, 3041.

15. Cardillo, G.; Orena, M.; Sandri, S. J. Org. Chem. 1986, 51, 713.

16. Di Nunno, L.; Franchini, C.; Scilimati, A.; Sinicropi, M. S.; Tortorella, P. Tetrahedron: Asymmetry 2000, 11, 1571.

17. Basford R. E. Methods Enzymol. 1967, 10, 96.

18. Matsumoto, T.; Suzuki, O.; Furuta, T.; Asai, M.; Kurikawa, Y.; Nimura, Y.; Katsumata, Y.; Takahashi, I. Clin. Biochem. 1985, 18, 126.

19. Kam, S. T.; Matier, W. L.; Mai, K. X.; Barcelon-Yang, C.; Borgman, R. J.; O’Donnel, J. P.; Stampfli, H. F.; Sum, C.Y.; Anderson, W. G. J. Med. Chem. 1984, 27, 1007. 
20. Ogata, M.; Matsumoto, H.; Takahashi, K.; Shimizu, S.; Kida, S.; Ueda, M.; Kimoto, S.; Haruma, M. J. Med. Chem. 1984, 27, 1142.

21. Tam, W. J. Org. Chem. 1986, 51, 2977.

22. Baldwin, J. J. Eur.Pat.Appl. EPXXDW EP 100068 (1984) to Merck and Co., Inc., USA.

23. Howson, W.; Kitteringham, J.; Mistry, J.; Mitchell, M. B.; Novelli, R.; Slater, R. A.; Swayne, G. T. G. J. Med. Chem. 1988, 31, 352.

24. Hamaguchi, S.; Hasegawa, J.; Kawaharada, H.; Watanabe, K. Agric. Biol. Chem. 1984, 48, 2055.

25. Wanderdam, E.G. J. C.; Brussee, J.; Van der Gen, A.; Kruse, C. G. Helvetica Chim. Acta 1994, 77, 252.

26. Junquera, F.; Merchàn, F. L.; Merino, P.; Tejero, T. Tetrahedron 1996, 52, 7045.

27. Pedrocchi-Fantoni, G.; Redaelli, S.; Servi, S.; Hogberg, H.-E. Gazz. Chim. Ital. 1992, 122, 499. 